\title{
Proses Pengambilan Keputusan dalam Situs Belanja Online "Shopee" sebagai Pemenuhan Kebutuhan Konsumen
}

\author{
Christine Pingkan Sampouw ${ }^{1}$, Astri Wulandari ${ }^{2}$ \\ 1,2 Fakultas IImu Komunikasi dan Multimedia Universitas Mercu Buana Yogyakarta, Yogyakarta, \\ Indonesia.christinepinkan@gmail.com, astri@mercubuana-yogya.ac.id*

\section{Decision Making Process in "Shopee" Online Shopping Site as Consumer Needs Fulfilling}

\begin{abstract}
Nowadays consumers are faced with many choices of ways to fulfill their wants and needs. Online shopping sites seem to be a fast way to be able to meet the shopping desires of today's consumers. Shopee has a variety of product categories offered to consumers. The collaboration between Shopee and endorsement also appears as an effort to maintain the existence of trends in an increasingly broad field. In this study it also appears that there is a diversity of backgrounds that shade each consumer's personality to use this market place. This is a qualitative research by doing indepth interview. The research subjects consisted of six informants with different backgrounds. The analysis technique is done by dividing two types of data, namely primary data from direct interviews, and secondary data from relevant articles. The purchasing decision-making process of consumers in buying products on the Shopee shopping site is done in a variety of ways based on their backgrounds and desires that emerge from within themselves. Therefore, it is not surprising that the decisions made by consumers appear to be different as changes in current shopping patterns, tertiary needs quickly change is if to be very primary to beat the real primary needs.
\end{abstract}

Keywords: Consumer Behavior; Decision making process; E-Commerce; Shopee

\begin{abstract}
ABSTRAK
Saat ini konsumen dihadapkan dengan banyak pilihan cara untuk memenuhi keinginan dan kebutuhannya. Situs belanja online seolah-olah menjadi satu cara cepat untuk dapat memenuhi hasrat belanja konsumen. Shopee memiliki beragam kategori produk yang ditawarkan kepada konsumen. Kerjasama antara Shopee dengan endorsement juga tampak sebagai upaya untuk menjaga eksistensi tren di bidang yang semakin luas. Pada penelitian ini juga tampak bahwa terdapat keragaman latar belakang yang menaungi masing-masing kepribadian konsumen untuk menggunakan market place ini. Jenis penelitian ini adalah kualitatif dengan menggunakan metode wawancara mendalam. Subjek penelitian terdiri dari enam informan dengan latar belakang perilaku konsumen yang berbeda-beda. Analisis dilakukan dengan membagi dua jenis data yakni data primer dari wawancara langsung, dan data sekunder dari artikel yang relevan. Proses pengambilan keputusan pembelian para konsumen dalam membeli produk dalam situs belanja Shopee dilakukan dengan beragam cara berdasarkan latar belakang dan keinginan dari dalam diri masing-masing. Oleh karena pengambilan keputusan yang dilakukan oleh konsumen menjadi berbeda-beda seiring berubahnya pola belanja saat ini. Kebutuhan tersier dengan cepat berubah seolah-olah menjadi sangat primer mengalahkan kebutuhan primer yang sesungguhnya.
\end{abstract}

Kata kunci: Perilaku Konsumen, Proses pengambilan keputusan, E-Commerce, Shopee

*corresponding author

Received: 03-02-2020

Acceptance: $28-04-2020$

Revision: 06-02-2020

Published online: $30-05-2020$ 


\section{PENDAHULUAN}

Pada praktiknya, tanpa disadari, seorang konsumen akan melewati beberapa proses untuk sampai pada tahap pengambilan keputusan. Riset perilaku konsumen dilakukan untuk melihat bagaimana pola pikir konsumen bekerja untuk memuaskan keinginan serta kebutuhan konsumen dan apakah inovasi tentang konsep pasar itu sendiri nantinya dapat mempengaruhi konsumen dalam mengambil keputusan?

Efisiensi pasar terjadi akibat hilangnya satu atau lebih perantara yang ada dalam suatu supply chain. Efisiensi operasional terjadi melalui hilangnya proses bisnis yang tidak efisien. Akses pasar terjadi dengan terbukanya jaringan yang lebih luas untuk melakukan bisnis, dan linkage, melalui kemampuan e-commerce untuk menghubungkan dan mengintegrasikan ke dalam rantai pasokan global (Molla \& Heeks, 2007).

Fenomena ini juga terjadi di Indonesia. Berdasarkan data dari Berita Kementerian kominfo.go.id, melalui artikel berjudul "Menkominfo: Pemerintah Dorong Pertumbuhan $e$ Commerce Indonesia", mulai pada tahun 2014 pemerintahan Indonesia berorientasi pada pengembangan bisnis e-commerce (Kemenkominfo, 2015). Shopee banyak melakukan strategi menarik sebagai pemikat untuk menumbuhkan brand awareness. Setelah menjalin kerjasama dengan Black Pink dan Christiano Ronaldo sebagai endorsement, market place ini membuat sebuah gebrakan ketika Tokopedia sebagai e-commerce pesaing membawa Bangtan Boys (BTS) sebagai endorsement. Strategi tersebut lalu dipatahkan lagi oleh Shopee dengan menguatkan tren yang tidak lagi membawa endorsement luar tetapi mengusung Didi Kempot yang sedang trending dan memiliki jumlah massa yang besar untuk diangkat menjadi Ambasador dengan istilah Brand Ambyarsador.

Sudah bukan rahasia lagi bahwa Indonesia memiliki potensi pasar yang besar di mata para entrepreneur, lokal maupun luar negeri. Dengan penetrasi mobile yang semakin kencang, berbagai peluang bisnis baru pun turut terbuka dan salah satu yang mulai naik ke permukaan adalah mobile e-commerce marketplace. Di sektor ini ada Shopee Indonesia yang berambisi jadi salah satu pemain yang memimpin sektor $\mathrm{C} 2 \mathrm{C}$ mobile marketplace di Indonesia. Ada pun beberapa tampilan market place online Shopee Indonesia adalah sebagai berikut:

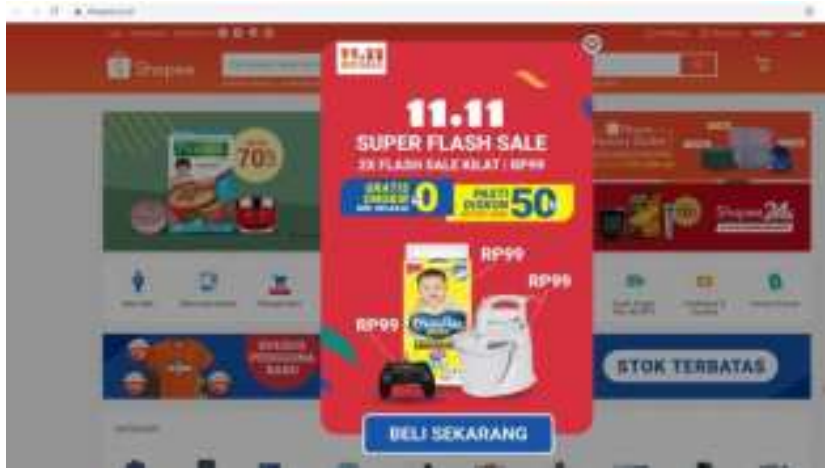

Gambar 1. Promosi Pada Tampilan Awal Shopee 


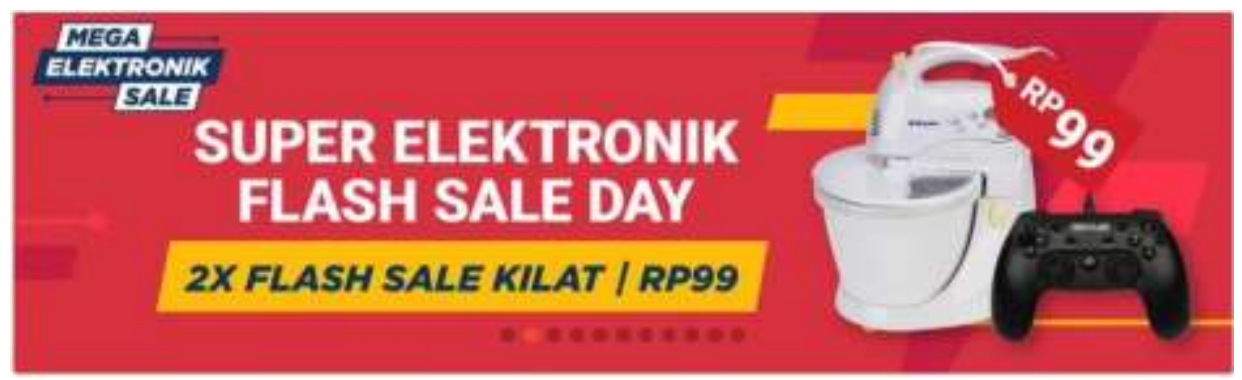

Gambar 2. Flash Sale Day Shopee

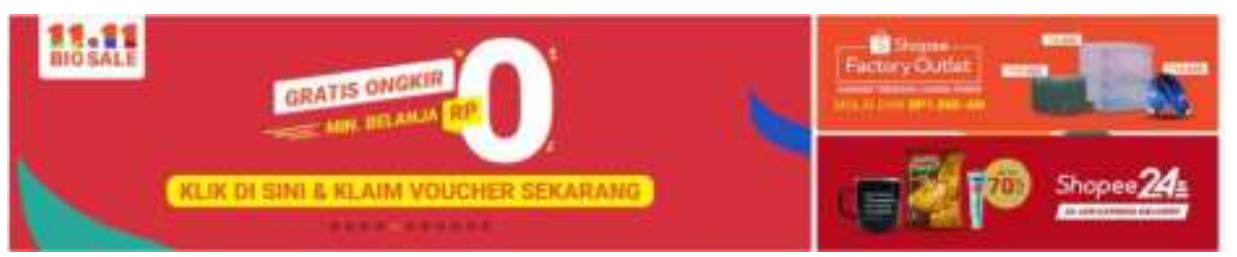

Gambar 3. Promo Gratis Ongkir

Ada beberapa manfaat yang didapat antara penjual dan pembeli dari belanja online shopping yaitu transaksi dapat dilakukan tanpa harus bertatap muka dengan penjual sehingga penjual dan pembeli dapat menghemat waktu, pilihan yang ditawarkan kepada pembeli semakin luas dan dapat mempertimbangkan harga dan model fisik melalui foto antara produk yang satu dengan yang lain dengan matang sebelum membeli produk. Bagi penjual, keuntungannya adalah mereka tidak perlu menyediakan tempat berdagang dan membayar pegawai, penjual dapat memasarkan produknya lebih luas ke dunia global melintasi batas wilayah/kota bahkan negara.

Di sisi lain terdapat pula risiko yang menimbulkan kekhawatiran bagi para pelaku belanja dan bisnis online. Kekhawatiran yang timbul dari dilakukannya transaksi secara online adalah keberadaan yang sulit dilacak antara pembeli dan penjual karena mereka tidak bertatap muka secara langsung. Selain itu masalah lain yang sering muncul dari transaksi online adalah adanya masalah penipuan kartu kredit, kurangnya privasi, risiko pengiriman, kurangnya jaminan kualitas barang dan jasa. Oleh karena itu peneliti melihat bahwa adanya sebuah hal penting yang harus diteliti terkait dengan perilaku konsumen sebagai pendekatan penting untuk melihat latar belakang konsumen yang konsisten masih berbelanja di shopee.

Banyak kategori produk yang dijual melalui Shopee yaitu gadget, laptop, fashion, perlengkapan bayi dan balita, elektronik, komputer, otomotif dan lain- lain (shopee.co.id). Begitu banyaknya kategori produk yang dicantumkan dalam situs membuat banyak pilihan juga bagi konsumen untuk memilih atau mencari produk-produk yang diminatinya. Kategori yang begitu banyak akan menarik minat konsumen untuk melakukan pencarian dan melakukan transaksi jual-beli sehingga kepercayaan mengenai keamanan dalam transaksi, ketepatan pengiriman barang serta mengatasi keluhan konsumen harus diperhatikan oleh Shopee. Hal tersebut juga menjadi perhatian bagi konsumen mengingat transaksi yang dilakukan dalam belanja online antara penjual dan pembeli tidak melakukan tatap muka 
sehingga kredibilitas situs menjadi salah satu hal yang juga diperhatikan oleh konsumen sehingga transaksi jual-beli dapat terus dilakukan.

Cara yang dilakukan Shopee tentu saja langsung menjadi trending topic di berbagai media sosial, baik Instagram hingga Twitter di tahun 2019. Sebagai sebuah e-commerce, Shopee memiliki banyak varian produk untuk memenuhi semua kebutuhan konsumen. Kategori yang begitu banyak akan menarik minat konsumen untuk melakukan pencarian dan melakukan transaksi jual-beli sehingga kepercayaan mengenai keamanan dalam transaksi, ketepatan pengiriman barang serta mengatasi keluhan konsumen harus diperhatikan oleh Shopee. Hal tersebut juga menjadi perhatian bagi konsumen mengingat transaksi yang dilakukan dalam belanja online antara penjual dan pembeli tidak melakukan tatap muka sehingga kredibilitas situs menjadi salah satu hal yang juga diperhatikan oleh konsumen sehingga transaksi jual-beli dapat terus dilakukan. Oleh sebab itu, penelitian ini akan fokus terhadap bagaimana proses pengambilan keputusan dalam situs belanja online Shopee sebagai pemenuhan kebutuhan konsumen.

\section{METODE}

Penelitian ini menggunakan pendekatan kualitatif, data yang dikumpulkan adalah data yang berhubungan dengan latar belakang dan perilaku konsumen dalam melakukan pembelian online, seperti bagaimana tanggapan konsumen mengenai online shop baik dari segi keamanan, keuntungan dan kerugiannya kemudian sumber informasi yang diperoleh konsumen terkait situs belanja online Shopee serta keunggulan yang dimiliki oleh Shopee sehingga pada akhirnya terjadi transaksi atau konsumen memutuskan untuk melakukan pembelian melalui Shopee.

Subjek penelitian adalah konsumen yang memahami informasi tentang berbelanja online dan telah melakukan pembelian produk melalui situs online shopping shopee.co.id. sekurang-kurangnya dua kali. Alasan dipilihnya Shopee sebagai objek penelitian adalah karena Shopee pernah menjadi topik nasional terkait penggunaan model Blackpink, namun berdasarkan Map E-Commerce, Shopee berhasil mempertahankan posisi pertamanya sebagai top e-commerce berdasarkan ranking PlayStore pada tahun 2019.

\section{HASIL DAN PEMBAHASAN}

Keputusan pembelian dapat dilihat lebih dalam dengan meminjam pendekatan teori yang telah dijabarkan oleh Kotler dan Armstrong, dimana konsumen pada dasarnya dianggap melewati lima tahap untuk melakukan pembelian, yakni: 1) Pengenalan kebutuhan 2) Pencarian informasi 3) Evaluasi alternatif 4) Keputusan pembelian dan ke 5) Perilaku paska pembelian. Lima hal ini menjadi check point analisis yang disinggung dalam analisis sebagai proses. Berdasarkan hasil penelitian tampak ada indikasi beragam hal menarik yang diasumsikan oleh peneliti sebagai proses pengambilan keputusan pembelian para konsumen, mulai dari pengenalan kebutuhan, pencarian informasi, evaluasi alternatif, keputusan pembelian, hingga perilaku paska pembelian. Hanya saja, mengingat bahwa subjek penelitian dalam penelitian ini telah menggunakan Shopee sebagai $e$-commerce yang 
dipercaya oleh konsumen oleh sebab itu maka bagian pengenalan masalah atau pengenalan kebutuhan, cenderung berkisar pada penjabaran mengenai alasan pemilihan Shopee sebagai e-commerce.

\section{Pengenalan Kebutuhan}

Keputusan pembelian merupakan rangkaian proses yang melihat proses sejak awal konsumen memiliki hasrat untuk membeli sampai dengan perilaku paska pembelian. Keputusan pembelian konsumen adalah proses pengintegrasian yang mengkombinasikan pengetahuan untuk mengevaluasi dua atau lebih perilaku alternatif, dan memilih salah satu di antaranya. Mengambil keputusan untuk membeli sesuatu bukanlah hal yang langsung terjadi begitu saja.

Pengenalan kebutuhan ini diperlihatkan melalui kebutuhan pada kebutuhan seharihari. Adapun beberapa produk yang dikonsumsi oleh konsumen merupakan produk yang sebenarnya banyak ditemui dan mudah dijangkau disekitar kita seperti paket data, dan pembayaran token listrik. E-Commerce berlomba-lomba untuk dekat dengan permasalahan sehari-hari dengan menyediakan jasa pembayaran tidak hanya menyediakan produk berupa barang.

Ketersediaan produk berupa barang dan jasa dalam satu space seperti sebuah bentuk perhatian dan kejelian Shopee dalam membaca keinginan dan kebutuhan konsumen masa kini yang menyenangi hal-hal yang sifatnya instan. Seorang pelajar butuh paket data sampai sepatu, seorang karyawan butuh token listrik, paket data, dan tambahan produk wajah atau skin care bagi karyawan perempuan. Berikutnya, konsumen dengan kriteria lainnya cenderung memiliki kebutuhan yang sama seperti alat-alat rumah tangga, pakaian pribadi dan pakaian anak. Hal tersebut berlaku bagi konsumen dengan latar belakang konsumen yang sudah berkeluarga.

\section{Pencarian Informasi: Proses Menuju Evaluasi Pribadi}

Setelah melihat pada analisis mengenai pengenalan kebutuhan konsumen, peneliti melanjutkan analisis pada bagian pencarian informasi. Hasil penelitian dari penjabaran pada proses ini sangat beragam, sebab referensi atau sumber yang menginisiasi informasi dapat ditemukan di mana saja.

Menurut Kotler dan Armstrong (2008) dijelaskan bahwa pencarian informasi adalah kondisi ketika seseorang yang sudah mengetahui apa yang menjadi kebutuhan kemudian mencari informasi secara aktif mengenai produk untuk memenuhi kebutuhannya. Pencarian informasi ini dapat dilakukan melalui beberapa sumber, seperti sumber pribadi (keluarga, teman), sumber komersial (iklan, kemasan, situs web), sumber publik (media massa, pencarian internet), dan sumber pengalaman (penanganan, pemeriksaan, pemakaian produk) (Kotler \& Amstrong, 2008).

Berdasarkan hasil penelitian setidaknya ditemukan ada empat unsur yang menjadi komunikator atas informasi ini, yakni: Instagram (melalui influencer, iklan, dan akun online shop di Instagram), keluarga, teman, dan iklan TVC. Dari empat hal yang disebutkan, 
Instagram adalah sumber yang paling banyak disebutkan. Hal ini relevan dengan survei yang dilakukan oleh The Asian Parent pada 1.099 ibu usia 18 hingga 44 tahun di Jabodetabek, Surabaya, Yogyakarta, Medan, dan Bandung dengan menyebutkan internet telah menjadi medium utama para ibu untuk mencari info seputar anak (Khalika, 2018). Disebutkan pula bahwa rata-rata 49 persen perempuan mengonsumsi lebih banyak internet setelah menjadi ibu berdasarkan penelitian yang diterbitkan pada 2018 itu. Hal ini dikarenakan mereka membutuhkan informasi yang lebih soal pengasuhan anak dan internet menjadi cara tercepat dan termudah untuk menemukan hal tersebut.

Menariknya, dalam penelitian ini, konsumen menyebutkan unsur teman, keluarga, dan iklan TVC sebagai sumber pencarian informasi. Tiga hal ini justru lepas dari media sosial atau internet. Kondisi ini relevan dalam kaitannya dengan perasaan psikologis dari konsumen dalam menentukan pilihannya. Artinya, jika internet adalah sarana untuk mencari informasi secara mandiri, keberadaan keluarga, teman, dan iklan TVC bisa jadi memberikan informasi pada konsumen secara lebih halus dalam kondisi pasif konsumen. Fahera melalui artikel berjudul Faktor Internal dan Eksternal ini Memengaruhi Keputusan Belanja menyebut bahwa keluarga, teman, dan iklan memiliki peran dalam membentuk suasana hati atau situasi yang nantinya dapat meyakinkan konsumen dalam memilih produk yang ingin dibeli (Fahera dalam Brilio, 2019).

Setelah membahas mengenai informasi dari Instagram, teman, dan keluarga sebagai rujukan, masih ada satu hal lagi yang memberikan dampak bagi konsumen dalam mencari informasi. Hal itu adalah iklan TVC. Seperti yang diketahui, Shopee adalah salah satu ecommerce yang rajin membawa endorsement besar dalam beriklan. Pada akhir tahun 2018, Shopee menggandeng Black Pink, grup penyanyi perempuan asal Korea Selatan yang dibentuk di bawah naungan YG Entertainment. Popularitas Black Pink yang dikaitkan dengan upaya meningkatkan citra Shopee tidak dapat dipandang sebelah mata. Masyarakat Indonesia terkena dampak dari penggunaan iklan tersebut, yakni dapat dilihat dari semakin banyaknya orang yang menyanyikan lagu Black Pink berjudul "DDU-DU DDU-DU" melalui Youtube. Artinya, endorsement ini tidak hanya membuat konsumen mengenal Black Pink saja, tetapi lebih dari itu. Shopee berhasil memantik keinginan konsumen dan calon konsumen paska menonton tayangan iklan yang disiarkan di televisi dengan mengajak sekumpulan idola yang sedang naik daun.

Kesimpulan dari bagian ini adalah bahwa media sosial tidak dapat dilepaskan dari medium informasi yang diakses oleh konsumen, khususnya melalui iklan di Instagram. Selain itu, iklan TVC dan informasi dari orang-orang terdekat seperti keluarga juga masih kuat menjadi sumber informasi. Hanya saja ada alternatif sumber informasi yang lain seperti influencer untuk produk tertentu.

\section{Evaluasi Alternatif Sebagai Perencanaan Keinginan}

Pencarian informasi pada dasarnya adalah suatu tahapan untuk mencapai evaluasi alternatif, sehingga konsumen mulai melihat pada banyak pilihan sebelum akhirnya dapat memutuskan suatu pembelian. Beberapa informasi dari Instagram, teman, dan keluarga, 
seperti yang telah disebutkan pada sub sebelumnya, berperan dalam memberi informasi alih-alih sebagai sarana mengolah evaluasi alternatif. Menurut Kotler (2008) dijelaskan bahwa evaluasi alternatif adalah kondisi ketika seseorang telah mendapat banyak informasi kemudian akan menggunakan informasi untuk mengevaluasi produk alternatif dalam beberapa pilihan (Kotler \& Amstrong, 2008). Secara lebih lanjut proses evaluasi ini tergantung pada konsumen pribadi dan situasi pembelian tertentu. Evaluasi alternatif pilihan produk yang dilakukan akan membentuk peringkat merek dan niat pembelian.

Konsumen yang mengalami evaluasi alternatif dengan melibatkan perasaan untuk mendapatkan kemudahan saat sedang dalam masa percobaan, terjadi ketika konsumen sedang mengalami masa transisi. Hal ini terjadi saat konsumen tidak langsung tertarik untuk mengakses Shopee karena kebiasannya dalam melakukan transaksi belanja secara konvensional. Pada saat konsumen mulai mengetahui bahwa dalam market place tersebut memiliki fitur paylater dan credit card, keinginan untuk berbelanja di Shopee mulai muncul secara perlahan. Hal ini tidak dapat dipungkiri bisa terjadi karena adanya seruan cashback, atau fitur lainnya bagi konsumen yang memiliki credit card. Artinya, suatu evaluasi alternatif dapat muncul dari kebiasaan lama yang masih menjadi keseharian dari konsumen, sehingga keinginannya untuk melakukan pembelanjaan secara online awalnya hanya dianggap sebagai alternatif. Setelah mencoba, konsumen baru dapat memutuskan untuk tetap melanjutkan kebiasaan lama dalam berbelanja di toko konvensional, atau menaati beberapa syarat untuk bisa mendapatkan kemudahan dalam transaksi secara online.

Evaluasi alternatif yang terakhir merujuk pada harga yang ditawarkan antar market place. Berdasarkan observasi, dapat dilihat bahwa ada beberapa toko yang menjual berbagai produknya di berbagai platform. Oleh karena itu semestinya selisih harga antar market place online ini cenderung serupa. Namun, selisih ini menjadi berbeda jika dibandingkan dengan harga di toko offline. Perbedaan antara harga suatu produk yang dijual di Shopee dan di toko konvensional bisa jadi jauh berbeda. Hal ini dikarenakan dua faktor, yakni ketersediaan produk dan keberadaan toko retail di beberapa daerah.

Artinya kesimpulan dari bagian ini membicarakan mengenai argumentasi yang terbagi menjadi dua. Pertama, sebagian konsumen mengaku langsung tertarik dengan Shopee karena memiliki beberapa fitur seperti paylater dan "free ongkir" atau cashback di beberapa komoditas. Bahkan bagi konsumen seperti seorang ibu rumah tangga juga tidak ragu untuk kemudian berbelanja dengan intensitas tinggi setiap membeli kebutuhan untuk keluarga. Kedua, sebagian konsumen dengan perilaku tertentu, cenderung lebih sering mencari toko konvensional karena dianggap masih bisa diakses.

\section{Keyakinan Memilih dan Konsistensi Paska Pembelian}

Keputusan pembelian adalah tahapan lanjut dari evaluasi alternatif. Beberapa bagian dari evaluasi alternatif tampak begitu kuat menjadi suatu keputusan pembelian dari konsumen sehingga benar-benar yakin dalam memilih Shopee. Hanya saja, terdapat konsumen yang mulai semakin yakin menggunakan Shopee saat direkomendasikan oleh teman, namun ada konsumen yang tetap menggunakan aplikasi tersebut saat seorang 
teman mulai beralih. Pada asumsi ini peneliti melihat bahwa keputusan pembelian dari konsumen mulai tampak semakin kuat dan meminimalisir rasa ragu. Menurut Kotler dan Armstrong (2008) dijelaskan bahwa keputusan pembelian adalah kondisi seseorang ketika telah memutuskan untuk membeli namun tidak langsung memilih merek atau produk yang disukai tapi terdapat dua faktor yang mendasari (Kotler \& Amstron, 2008). Faktor pertama yaitu sikap orang lain, di mana konsumen akan mempertimbangkan pendapat orang lain. Faktor kedua yaitu faktor situasional yang tidak diharapkan.

\section{Keputusan Pembelian Melalui Tren: Dampak Endorsement}

Keberadaan endorsement tidak dapat dipandang sebelah mata. Nyatanya idola memiliki dampak yang signifikan pada beberapa konsumen. Di tahun 2019, tepatnya pada promosi bulan September, Christiano Ronaldo menjadi endorsement yang begitu menarik. Penilaian muncul karena Shopee, di kurun waktu terakhir, cenderung dikenal sebagai online shop yang memiliki segmen pasar perempuan. Dilansir dari situs resmi media nasional Gatra, Julistian (2019) menyebut bahwa Shopee adalah salah satu e-commerce terbesar Indonesia yang memiliki segmen pasar pada kalangan perempuan. Pandangan umum ini diamini oleh Country Brand Manager Shopee, Rezky Yanuar, dalam kegiatan Exabytes ECommerce Conference yang diadakan di Citiwalk Sudirman pada 14 Agustus 2018. Fenomena ini yang membuat Shopee perlu untuk membentuk strategi baru dengan nama Shopee Man. Diketahui berikutnya strategi ini dilekatkan dengan nama "Shopee 9.9 Super Shopping Day" dengan mengajak Christiano Ronaldo, seperti yang diketahui dari aplikasinya langsung, iklan TVC, dan iklan di Youtube.

Tren pembelian di halaman awal yang dimaksudkan ini mengarah pada promosi Shopee 9.9 yang telah dijelaskan di bagian sebelumnya. Bahkan endorsement tersebut tampak mengindikasikan keberhasilan untuk memperluas segmen pasar, sehingga dalam Shopee 11.11, Christiano Ronaldo dimunculkan kembali. Peneliti melihat bahwa cara ini dapat dibaca sebagai soft selling dengan meyakinkan para konsumen untuk mengakses Shopee dengan mendekatkan konsumen dengan idola dari dunia sepakbola. Salah satu komoditas yang tampak erat dengan olahraga adalah produk sepatu.

Komisi Penyiaran Indonesia (KPI) pernah melarang 11 stasiun televisi menayangkan iklan Shopee-BlackPink (Tempo, 2018). Pada saat itu BlackPink sedang naik daun dan menjadi endorsement dalam program acara Shopee Road to 12.12 Birthday Sale. Menurut situs media Tempo, dalam referensi yang sama, KPI melihat bahwa BlackPink dianggap kontroversi dan berpotensi bertentangan dengan norma kesopanan yang dianut oleh masyarakat Indonesia. Menariknya, larangan ini tidak membuat para konsumen beralih dari Shopee sehingga memilih e-commerce lain untuk berbelanja secara online.

BlackPink sudah terlanjur besar, dan berarti semakin dikenal oleh banyak orang, yang bahkan hingga sekarang masih berpotensi memiliki dampak secara khusus pada para konsumen yang berbelanja di Shopee. Dilansir dari situs resmi Antara News (2019) disebutkan bahwa BlackPink masih menjadi idola yang mumpuni hingga sekarang. Kanal Youtube resmi grup ini diberitakan ada sejumlah 29.897 .163 pelanggan, yang beberapa 
diantaranya tentu adalah konsumen Shopee yang semakin senang saat idolanya menjadi endorsement besar dari e-commerce yang digunakannya. Atau sebaliknya, penggemar BlackPink yang masih belum mengenal Shopee bisa jadi beralih ke Shopee karena keberadaan idolanya ini.

Dapat disimpulkan bahwa konsumen akhirnya menjatuhkan pilihan keputusan pembelian pada Shopee karena beragam kebutuhan, seperti kebutuhan pribadi, kebutuhan pekerjaan, dan kebutuhan mendadak yang sangat diperlukan. Dilengkapi kemudian bahwa keputusan pembelian pada Shopee dilakukan juga karena adanya fitur chat real time, konfirmasi, dan tracking barang real time, serta rating penjual atau produk. Untuk konsumen yang juga melakukan pembelian pada beberapa barang yang berhubungan dengan pekerjaan mereka juga mengandalkan fitur tertentu sebagai sebuah hal yang meyakinkan dan untuk konsumen tertentu menganggap Shopee memiliki produk berupa barang yang cukup untuk memenuhi kebutuhan penampilan, seperti pakaian, sepatu, gel rambut atau pomade, dan aksesoris gadget. Selebihnya, bagi para ibu rumah tangga Shopee menjadi penting karena kelengkapan ketersediaan produk berupa barang kebutuhan keluarga sehari-hari, serta program flash sale yang terkenal dengan potongan harga. Artinya, potongan harga ini sering dimanfaatkan oleh beberapa konsumen untuk memenuhi kebutuhan keluarga. Saat sudah terbiasa berbelanja di Shopee seperti demikian, maka mereka mulai kehilangan hasrat dengan toko konvensional.

\section{Keputusan Pembelian: harga dan promosi sebagai implementasi klasifikasi kelas sosial}

Potongan harga, bebas biaya ongkos kirim, dan beragam promosi seperti cashback dan flash sale menjadi faktor utama penelitian ini. Pasalnya sebagian besar konsumen mengakui bahwa segala hal yang di indikasikan membuat harga komoditas lebih murah sehingga membuat mereka semakin meliriknya. Selain dari implikasi tren untuk membawa para konsumen pada keputusan pembelian yang semakin kuat, mereka memilih Shopee karena satu alasan besar yaitu harga yang terjangkau.

Potongan harga pun membuat konsumen tertarik untuk melihat dan memantau komoditas yang di inginkan. Belum lagi jika potongan harga tersebut masuk dalam kategori flash sale, yang artinya potongan harga yang diberikan memiliki harga yang jauh lebih murah daripada harga di pasaran. Fenomena demikian membentuk suatu budaya baru, yang bagi peneliti yaitu sikap impulsif dalam belanja.

Dalam hal pembiayaan pakaian yang dikenakan atau yang saat ini lebih akrab disebut dengan outfit, Handayani (2016) memberi keterangan riset yang dilakukan oleh Euromonitor terkait pengeluaran masyarakat Indonesia terhadap pembelian pakaian. Hasilnya memperlihatkan bahwa Indonesia adalah salah satu negara yang pasarnya tumbuh dengan kelas menengah potensial terbaik untuk tahun 2015-2020. Kelas menengah di Indonesia yang dimaksudkan pada hasil riset tersebut, berada di kelas menengah nomor empat terbesar di dunia dengan 17,3 juta rumah tangga pada tahun 2014, di mana tiga peringkat di atasnya diduduki oleh negara Amerika Serikat, India, dan Cina. Disebutkan pula potensi yang 
dimaksudkan diindikasikan melalui besarnya jumlah keluarga kelas menengah dan daya beli yang menguat sehingga perilaku belanja menjadi lebih leluasa.

Pada intinya bagian ini mengacu pada perilaku seseorang setelah ia membeli sebuah produk. Jika setelah membeli produk ia merasa puas, perilaku yang muncul adalah pembelian ulang. Jika tidak, maka akan kecil kemungkinan munculnya pembelian ulang pada produk tersebut. Keseluruhan subjek penelitian selaku konsumen Shopee pada penelitian ini tampak lebih puas sehingga perilaku yang muncul adalah pembelian ulang. Ada satu kesimpulan yang di dapat pada penelitian ini yaitu konsumen memilih untuk loyal menggunakan Shopee karena kepraktisan dan keterbiasaan mereka dengan situs belanja online ini.

\section{Faktor Penunjang}

Iklan mempunyai daya tarik yang begitu persuasif. Para konsumen tertarik dengan Shopee, alih-alih sebagai tempat berbelanja yang nyaman, karena market place tersebut memiliki beragam promosi yang membuat mereka merasa diuntungkan. Dari segala promosi tersebut peneliti melihat bahwa di antaranya menghasilkan keinginan untuk berbelanja seperti misalnya saat mereka mulai mencari tahu sepatu, aksesoris, produk kecantikan, hingga produk yang sesuai dengan tren saat ini (kekinian).

Konsumen yang berstatus sebagai pelajar dan belum memiliki penghasilan sendiri secara perilaku dapat saling berpengaruh antar satu konsumen pelajar dengan yang lainnnya sehingga mendorong terciptanya tren tertentu. Hal ini terjadi karena tampaknya dalam komunikasi di antara konsumen pelajar, mereka lebih suka saling bertukar informasi dalam konteks apa pun, mulai dari musik, fashion, hingga gaya hidup. Salah satu artikel dari Tempo (2018) pernah menuliskan bahwa pelajar (khususnya mahasiwa) sering menjadi segmen pasar suatu perusahaan. Industry Lead Digital Natives Facebook, Arjun Sarwal, saat peluncuran festival belanja online Shopee 11.11 Big Sale, mengemukakan hal yang menarik tentang salah satu platform media sosial mereka, konten di Instagram berpengaruh pada keputusan pembelian produk, bahkan dibandingkan dengan Facebook.

\section{SIMPULAN}

Penelitian ini bertujuan untuk memahami proses pengambilan keputusan pembelian para konsumen dalam membeli produk melalui situs belanja online Shopee sebagai pemenuhan kebutuhan. Melalui penjabaran yang telah dilakukan, dapat disimpulkan bahwa proses pengambilan keputusan pembelian para konsumen dalam membeli produk dilakukan dengan beragam cara berdasarkan latar belakang dan keinginan yang muncul dari dalam diri masing-masing. Oleh karena itu tidak heran jika pengambilan keputusan yang dilakukan oleh konsumen yang mana adalah seorang pelajar, pekerja, bahkan ibu rumah tangga menjadi berbeda-beda. Walaupun demikian seluruh kebutuhan mereka tetap terpenuhi dengan menggunakan medium smartphone, sebagai alat komunikasi masif di era digital. Alat ini telah begitu mengubah kelas kebutuhan di masyarakat, seperti yang tampak dari analisis, 
kebutuhan tersier dengan cepat berubah seolah-olah menjadi sangat primer mengalahkan kebutuhan primer yang sesungguhnya, yakni papan, sandang, dan pangan.

Selain itu, kerjasama antara Shopee dengan endorsement juga tampak sebagai upaya untuk menjaga eksistensi tren di bidang yang semakin luas. Christiano Ronaldo menjadi sosok yang menyublim sebagai tokoh belanja, yang sebelumnya lebih sering tampil di lapangan sepak bola sebagai bagian dari El Classico, Real Madrid. Artinya, hal ini seperti gimmick bagi para penggemar laki-laki untuk kemudian mengalihkan perhatian mereka menuju Shopee. Tren ini tidak hanya berhenti sampai di situ, sebab Blackpink juga masih punya andil bagi para penggemar K-Pop. Konsumen yang tadinya hanya tertarik dengan Girl Band tersebut dari lagu dan videonya, ditemukan kembali dalam situs belanja online Shopee. Di sisi lain, kepercayaan para konsumen tetap setia dalam menggunakan Shopee melibatkan teman, keluarga, dan kebutuhan yang terkait atas profesi. Pada penelitian ini tiga hal yang telah disebutkan tidak muncul secara bersamaan, sebab lebih tampak bergantung pada psikologis dari konsumen dalam menentukan pilihannya.

\section{DAFTAR PUSTAKA}

Kotler, P. \& Armstrong, G. (2008). Prinsip-prinsip Pemasaran, Edisi Keduabelas. Jakarta: Erlangga.

Kotler, P. \& Keller, K.L. (2008). Manajemen Pemasaran, Jilid 1. Jakarta: Penerbit Erlangga.

Fahera, J. (2019). Faktor internal \& eksternal ini memengaruhi keputusan belanja online. Brilio. https://www.brilio.net/creator/faktor-internal-eksternal-ini-memengaruhi-keputusan-belanjaonline-3656d6.html

Handayani, M.S. (2016). Biaya Bergaya Kelas Menengah Indonesia. Tirto. https://tirto.id/biayabergaya-kelas-menengah-indonesia-bUai

Julistian, Ucha. (2019). Dinilai Lebih Bernuansa Perempuan, Shopee Coba Gaet Pasar Pria. Gatra. https://www.gatra.com/detail/news/437435/technology/dinilai-lebih-bernuansa-perempuanshopee-coba-gaet-pasar-pria

Khalika, Nindias Nur. (2018). Shopee \& Instagram Tempat Belanja Online Favorit Ibu Milenial. Tirto. https://tirto.id/shopee-instagram-tempat-belanja-online-favorit-ibu-milenial-cY4h

Menkominfo. (2015). Menkominfo: Pemerintah Dorong Pertumbuhan e-Commerce Indonesia. Kementerian Komunikasi dan Informatika RI.

https://kominfo.go.id/index.php/content/detail/6020/Menkoinfo\%3A+Pemerintah+Dorong+Pertum buhan+e-Commerce+Indonesia/0/berita satker

Molla, A \& Heeks R. (2007). Exploring e-commerce benefits for businesses in a developing country, dalam Jurnal Information Society, vol. 23, no. 2, hal. 95-108.

https://researchbank.rmit.edu.au/view/rmit:332

Tarigan, M. (2018). Seberapa Banyak Media Sosial Pengaruhi Anda untuk Belanja?. Tempo. https://gaya.tempo.co/read/1139782/seberapa-banyak-media-sosial-pengaruhi-anda-untukbelanja/full\&view=ok 
Widyastuti, Rr. Ariyani Y. (2018). KPI Larang 11 Stasiun Televisi Tayangkan Iklan Shopee Blackpink. Tempo.

https://bisnis.tempo.co/read/1154561/kpi-larang-11-stasiun-televisi-tayangkan-iklan-shopeeblackpink

Zhafira, A.N. (2019). Geser One Direction, BLACKPINK jadi grup dengan subscriber terbanyak. Antara News. $\quad<$ https://www.antaranews.com/berita/1052788/geser-one-direction-blackpink-jadi-grupdengan-subscriber-terbanyak\#mobile-src>

\section{Laporan Wawancara}

Avelino, S. Putri, C. Wardani, Dyah Wahyu. Nugraha, Krisna Egi. Manihuruk, Louisa Meigytha. Larissa, Helga. (26 Agustus 2019). Personal Interview. 